\title{
Investigating the Determinants of Nonperforming Loans in the Romanian Banking System: An Empirical Study with Reference to the Greek Crisis
}

\author{
Sofoklis D. Vogiazas ${ }^{1}$ and Eftychia Nikolaidou ${ }^{2}$ \\ ${ }^{1}$ South East European Research Centre, CITY College and Research Centre of the University of Sheffield, 24 Proxenou Koromila Street, \\ 54622 Thessaloniki, Greece \\ ${ }^{2}$ Business Administration and Economics, CITY College_International Faculty of Sheffield University, Leontos Sofou Street, 54622 \\ Thessaloniki, Greece \\ Correspondence should be addressed to Sofoklis D. Vogiazas, svogiazas@seerc.gr
}

Received 21 June 2011; Revised 24 August 2011; Accepted 24 August 2011

Academic Editor: Ali M. Kutan

Copyright ( $) 2011$ S. D. Vogiazas and E. Nikolaidou. This is an open access article distributed under the Creative Commons Attribution License, which permits unrestricted use, distribution, and reproduction in any medium, provided the original work is properly cited.

\begin{abstract}
This paper aims to investigate the determinants of nonperforming loans in the Romanian banking sector by means of time series modelling. It is motivated by the hypothesis that macroeconomic-cyclical indicators, monetary aggregates, interest rates, financial markets, and bank-specific variables influence the nonperforming loans in the Romanian banking system. Using monthly series that span from December 2001 to November 2010, we cover both the booming period and the recent financial crisis. Given the significant presence of the Greek banks in Romania, the novelty of the paper lies in the introduction of variables that proxy the Greek crisis. Thus, we examine the existence of a potential transmission channel to the Romanian banking system by investigating the impact of the Greek crisis to the Romanian nonperforming loans. Our findings indicate that macroeconomic variables, specifically the construction and investment expenditure, the inflation and the unemployment rate, and the country's external debt to GDP and M2 jointly with Greek crisis-specific variables influence the credit risk of the Romanian banking system. The results have several implications for policymakers, regulators, and managers as the most recent published stress tests on the Romanian banking system are based on end 2008 data.
\end{abstract}

\section{Introduction}

The study of financial sector stability has become the cornerstone of modern macroeconomic policy. The recent global financial crisis highlighted the importance of appreciating financial institutions' vulnerabilities in the context of managing credit risk. The key motivation for this paper is to improve our understanding of the credit risk determinants by focusing on the Romanian banking system while casting a vigilant eye on potential contagion effects from neighbouring countries. This is particularly important given that the Romanian financial system is dominated by foreignowned commercial banks. Among them, the Greek banks' subsidiaries have a substantial presence as they hold 30.7\% of aggregate foreign capital while they account for the second largest market share in the Romanian banking system [1]. Therefore, any attempt of exploring the deterministic factors of the Romanian banks' credit risk should not be limited solely on endogenous variables of the respective economy.

Using time series modelling techniques, this paper empirically investigates the determinants of ex post credit risk as reflected on the loss loan provisions to total loans ratio for the Romanian banking system. Related to a growing body of literature, the purpose of the study is to offer an insight into the factors that determine the quality of the loan portfolio of Romanian banks. In this direction, it utilizes a broad dataset that spans from December 2001 to November 2010. The explanatory power of macroeconomic, Romanian bank-specific, monetary, interest rates and financial markets' variables is investigated. The key contribution of the paper 
lies in the introduction of proxies for the Greek debt crisis and the subsequent Greek banks' financial distress. The aim is to examine a potential transmission channel or spillover effects to the Romanian banking system. As the twin Greek crises unfold, any repercussion for the neighbours is possibly the most important issue in the minds of policy makers, regulatory bodies, and bankers. Furthermore, the time series utilised include both the booming period as well as the downturn following the financial crisis and the ensuing manifestation of Greece's structural weaknesses.

The paper is organized as follows. Section 2 presents an overview of the Romanian banking system while Section 3 presents the empirical literature that attempts to delineate the determinants of loan portfolio quality. Section 4 discusses the Nonperforming loans deterministic factors in the Romanian context while Section 5 examines the empirical results, potential limitations, and proposes future research direction. The paper concludes with Section 6.

\section{Overview of the Romanian Banking System}

The Romanian economy has evolved from a long history of defaults on sovereign debt, periods of high inflation, and banking crises. During the Great Depression period, many local and foreign banks in Romania collapsed or experienced heavy runs [2]. The crisis historical database indicates that in 1933 the redemption for domestic and foreign debt was suspended. In the post-World War II period the country experiences a debt crisis during the 1980s.

Barisitz [3] indicates that until 1998 the Romanian banking system was overwhelmingly state owned. Credit institutions granted loans to an unrestructured real sector dominated by inefficient state-owned factories, subject to "quasiautomatic" refinancing by the Central Bank of Romania, which conducted an accommodative monetary policy. Thus, there is no surprise in the fact that bad loans were a serious problem for all economies in the SEE region due to inherited legacies but also to continuing lending practices [4]. In Romania, the dominant state-owned banks accumulated large portfolios of defaulted loans and required massive capital injections from the government. Furthermore, severe macroeconomic shocks led to banking crises and economic growth resumed only after these crises were resolved.

By the end of the 1990s the Romanian government carried out legal reforms through the new central bank law. Retrospectively, the year 1999 proved to be a sort of structural turning point for the Romanian economy as the authorities initiated the first privatizations of major Romanian banks. Given the size of the country, the Romanian financial sector offered an impressive growth potential for foreign strategic investors. Figures 1 and 2 depict the current situation in the Romanian banking system.

The following years up to the burst of the global financial crisis were characterised by rapid credit growth. That was thought to be part of the ongoing process of financial deepening given that the credit to GDP ratio still remains at relatively low levels. On the other hand concerns were

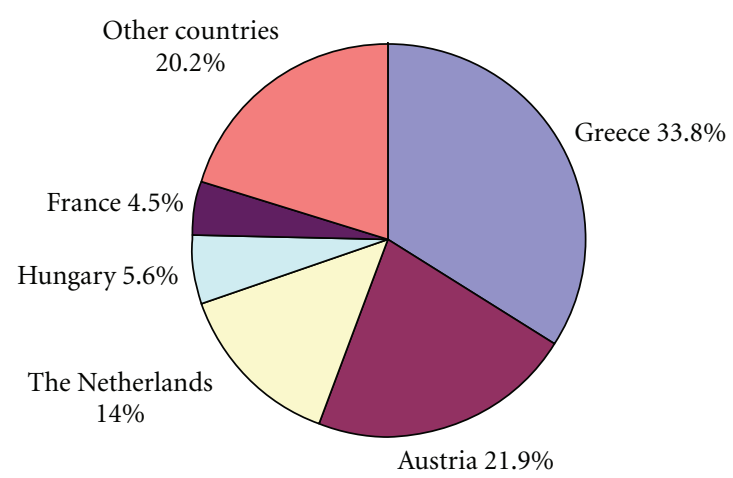

Source: National Bank of Romania

FIGURE 1: Structure of credit institutions' share capital by country of origin (H1: 2010).

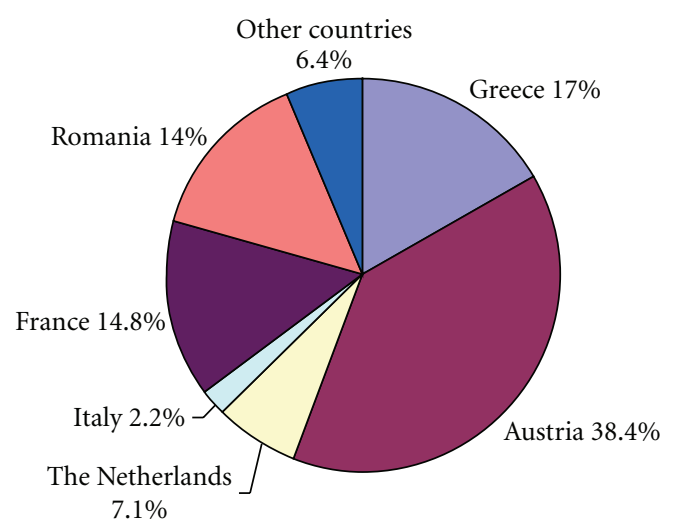

Source: National Bank of Romania

FIGURE 2: Market share of credit institutions by structure of shareholding (H1: 2010).

raised whether the economy was experiencing a credit boom, a situation where credit expands at an unsustainable pace.

It has been argued that the presence of foreign banks in Romania has increased the efficiency of financial intermediation and the availability of credit to the real economy. Yet, there are indications that financial stress originating in Euro area-based parent banks may have been transmitted to Romania. The lending survey of the National Bank of Romania (NBR) indicates that the risk profile of almost all industries rose with the riskiest sectors being construction and real estate, thus, reflecting the adverse impact of the global financial crisis. The outlook for the Romanian banking system remains negative, driven mainly by the tough economic conditions in the country following a severe recession in 2009 [5]. The deteriorating operating environment in Romania is characterised by a contracting economy, widened fiscal deficit, and rising unemployment. In particular, the country's macroeconomy appears to the main source of concern for Romanian banks given the sharp increase in the level of nonperforming loans. Furthermore, the high proportion of foreign currency lending mainly to 
households elevates their credit risk profile while the stressed liquidity as reflected in the system's loan-to-deposit ratio (the loan-to-deposit ratio is at relatively high levels reflecting the Romanian banks' reliance on wholesale-parent bank funding) may lead to a further tightening on the supply side of credit.

\section{Empirical Literature Review}

This section reviews the empirical work on the relation between macroeconomic variables and the loan portfolio quality or credit risk (the framework for studying the impact of macroeconomic variables or the business cycle on credit risk is represented by two competitive theories. The first one stresses that credit risk is procyclical whereas the second one defends the countercyclical view). Many studies investigate the factors that induce financial crises by examining potential links between bank-specific variables and macroeconomic factors.

Delving into the specifics of the crises literature, Gavin and Hausmann [6] argue that excessive credit growth is a primary factor behind banking crises as usually it reflects a decline in the credit standards. Examining the macroeconomic factors that contributed to banking crises in Latin America during the 1990s, the authors find that interest rates, expected inflation, terms of trade, domestic income, credit growth and the monetary and exchange rate regime are important constraints on loan servicing capacity. Similar results can be found in Diamond and Rajan [7]. Demirgüç-Kunt and Detragiache [8] theorize that banks face insolvency due to falling asset values when bank borrowers are unable to repay their debt as a result of adverse shocks to economic activity. Using a multivariate logistic model for a large sample of developing and developed countries during 1980-1994, the authors find that inflation and the real interest rate are positively associated with a banking crisis whereas the GDP has an inverse relationship. Furthermore, the study by Hardy and Pazarbasioglu [9] strongly suggests that the likelihood of banking system distress is largely in accord with declining economic growth. The authors also find that capital inflows and credit expansion to private sector, associated with rising consumption and real interest rates, typically precede banking crises.

An increasingly popular method of assessing financial sector vulnerabilities is the macro stress-testing approach (the term refers to a range of techniques used to assess the vulnerability of a financial system to "exceptional but plausible" macroeconomic shocks). Relevant studies examine the link between banks' loan losses, or Nonperforming loans, and macroeconomic factors. The most common approach in similar studies involves estimating on historical data the sensitivity of banks' balance sheets to adverse changes in macro fundamentals. Then the estimated coefficients can be used to simulate the impact on the financial system of possible stress scenarios in the future. The focus is on credit risk, which by large represents the most significant risk faced by banking systems worldwide.

Two main strands of the literature can be identified in this area, building on the seminal works by Wilson $[10,11]$ and Merton [1]. Merton [1] models initially the response of equity prices to macro fundamentals and then maps asset price movements into default probabilities. On the other hand, Wilson's $[10,11]$ framework allows the direct modelling of sensitivity of default probabilities in various industrial sectors to the evolution of a set of macroeconomic variables. Studies analysing the macroeconomic determinants of banks' loan losses or Nonperforming loans include Pesola [12] for the Nordic countries, Kalirai and Scheicher [13] for Austria, and Delgado and Saurina [14] for Spain. Typically, these studies find that loan loss provisions are negatively related to GDP growth and positively related to interest rates. Kalirai and Scheicher [13] estimate a time series model of aggregate loan loss provisions in the Austrian banking system as a function of an extensive array of macroeconomic variables. Results indicate that a rise in short rates, a fall in business confidence, a decline in the stock market, and a decline in industrial production have an impact on the loss loan provisions.

Since the seminal work of Sims [15], the VAR approach to empirical investigation of monetary policy shocks has gained momentum. Several studies have used the VAR models (studies that employ VAR models include Blaschke et al. [16], Hoggarth et al. [17], Delgado and Saurina [14], Gambera [18], and Baboucek and Jancar [19]) to investigate the macro fundamentals transmission mechanism in the United States and other countries (these models are used in the studies developed at the central banks of the UK, Japan, Spain, the Netherlands, and at the European Central Bank). These models include various macroeconomic factors, ranging from a number from two to five depending on the country. In some cases variables more directly related to the creditworthiness of firms are added, such as measures of indebtedness. In other cases, market-based indicators of credit risk, such as equity prices and corporate bond spreads are used (introducing market variables such as interest rates, foreign exchange rates, and equity and real estate price indices into credit risk models is a way of explicitly integrating the analysis of market and credit risks). Foglia's [20] survey indicates that researchers increasingly adopt models that are more flexible and easier to use, such as VARs and other strictly statistical rather than structural models. The estimation process normally requires the selection of a set of macroeconomic and financial variables that, according to economic theory and empirical evidence, affect credit risk. In this regard, variables such as economic growth, unemployment, interest rates, equity prices, and corporate bond spreads contribute to default risk [20].

Several recent papers $[21,22]$ analyse the impact of macro fundamentals on the credit quality of banks' debtors using the framework of Wilson [10, 11]. Virolainen [23] estimates a macroeconomic credit risk model for the Finnish corporate sector over the period from 1986 to 2003 (a distinguishing feature of the study is that the sample period used to estimate the model includes a severe recession and a banking crisis). The SUR model results suggest a significant relationship between corporate sector default rates and key macroeconomic factors including GDP, interest rates, and corporate indebtedness. As in most studies, the 


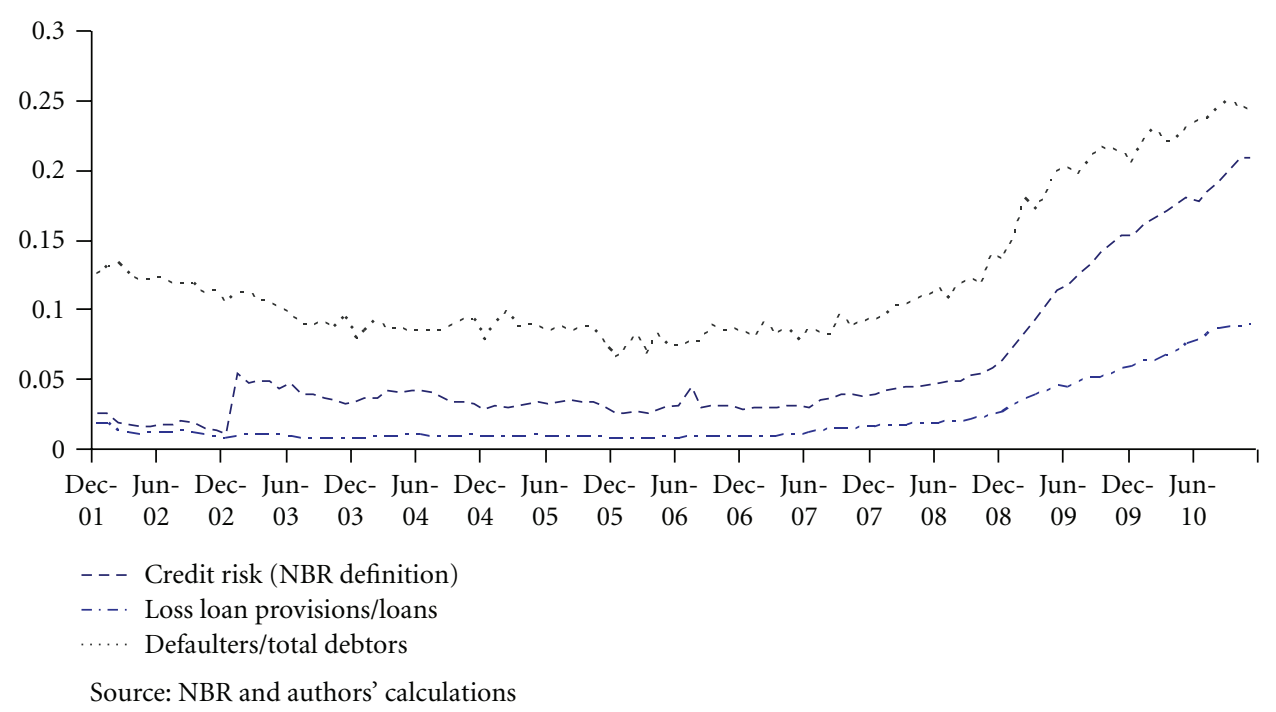

FIgURE 3: Credit risk in the Romanian banking system.

estimated model is employed to analyse corporate credit risks conditional on current macroeconomic conditions, that is, stress testing. The findings are in line with previous studies using observed bankruptcies for default rate measures.

Following Virolainen [23] methodology, Trenca and Benyovszki [22] estimate a macroeconomic credit risk model for the Romanian corporate sector over the period 20022008. Results suggest a significant relationship between industry-specific default rates and macroeconomic factors such as GDP growth rate, consumer price index, real interest rate charged on loans, the exchange rate, and industryspecific indebtedness. Boss [21] estimates a macroeconomic credit risk model for the aggregate corporate default rate to analyse stress scenarios for the Austrian banking sector. Findings suggest that industrial production, inflation, the stock index, the nominal short-term interest rate, and the oil price are the most important determinants of corporate default rates.

A leading role in the development of aggregate stress tests has been performed by the IMF, in cooperation with the World Bank. In 2005 the IMF conducted for the first time in Greece a financial sector assessment program [24]. Similar to Boss [21], Kalfaoglou [24] emphasises that credit risk remains the most important risk in the Greek banking sector. Despite the satisfactory stress tests' results, the author indicates that the cross-border expansion of banks increases their vulnerability to external shocks which, in turn, requires better and more intensive risk management practices. The IMF's [5] Romanian stress tests indicate that the financial system is particularly vulnerable to the effects of further slowing or reversal of capital inflows and associated downward pressure on the exchange rate. The stress tests were based on data to end June 2008 (it is worth noting that the 2010 EU-wide stress test exercise did not consider the Romanian banks). Thus, the exercise takes no account of developments in macrofinancial variables and balance sheets since then. Furthermore, it does not explicitly assess the impact of the sharp slowing of lending, either as a result of tightening credit standards or in response to reduced funding from foreign parent banks.

The above-mentioned studies, in general, corroborate theoretical postulates with respect to the macroeconomic influences on loan portfolio quality and, consequently, on banking sector stability. In effect, good economic conditions seem to be commensurate with good loan quality measured by either the nonperforming loans' ratio or loan loss provisions.

\section{Deterministic Factors of Nonperforming Loans in Romania}

Following the empirical literature reviewed, the primary hypothesis under test is that credit risk (credit risk is the risk that a counter-party or obligor will default on their contractual agreement. Financial institutions typically cover expected losses through appropriate provisioning) is sensitive to macroeconomic, cyclical, financial markets and bank-related factors. Therefore, the variables' selection for the empirical part of the study is based on the indicators presented in related studies to ensure comparability of results.

This paper follows the provisioning approach. The dependent variable, credit risk, is defined as the ratio of loss and doubtful loans to total loans (LLP ratio). Several studies have used Nonperforming loans, loan loss provisions, or composite indices as the metrics to assess the vulnerability of the financial system over time. Alternative indicators considered in this study to measure the credit quality of the Romanian banking system were the credit risk ratio as defined by the NBR and the ratio of total loan defaulters to total debtors. The empirical results obtained when we used the alternative metrics were poor and inconsistent (that may be due to structural breaks in the series that could not be attributed to the financial crisis. They may arise as a result of changes in monetary regulation or reporting standards). All credit risk indicators considered are plotted in Figure 3. They 
all exhibit an increasing trend, thus, signalling deterioration in the quality of Romanian credit portfolio.

The increasing level of provisions (LLP ratio) reflects the declining asset quality of the Romanian banking system. IMF [5] reiterates that credit deterioration is the primary risk to the banking sector. A sharp rise in nonperforming loans coupled with weak growth prospects and exchange rate depreciation impairs the ability of households and corporations to service their debts.

The complete set of the exogenous variables considered can be viewed in Table 3 in the Appendix. For presentation purposes, we divided the variables into six broad categories: macroeconomic-cyclical indicators, monetary indicators, interest rates' indicators, financial markets indicators, Romanian bank-specific indicators, and Greek fiscal crisis and bank-specific indicators.

The macroeconomic-cyclical indicators used are the GDP (the seasonally adjusted gross domestic product in nominal terms has been used. The interpolation method used to transform the macroeconomic data frequency is the quadratic (match average) method. Results should be considered as suggestive since observing a series at a lower frequency provides fundamentally less information than observing the same series at a higher frequency), the unemployment rate, the consumer price index, the foreign direct investment, the investment expenditure (gross fixed capital formation), the construction (anecdotal information suggests that the property market in Romania has weakened considerably after the global financial crisis. A sharp contraction in capital inflows may lead to a major slump and unemployment in the construction sector, with adverse consequences for Nonperforming loans) expenditure, the total consumption, and the household consumption and the foreign trade captured by the country's imports and exports. The current account is also expected to exert a significant role as for many developing economies workers' inward remittances save the current account from becoming an unmanageable deficit. A sharp contraction of inflows could threaten the financial stability through a drying up of credit to the private sector, resulting in a slump of economic activity and an increase of loan defaults. The "bad habit" of debt growth is also incorporated in the dataset as its dynamics may deteriorate the real economy and subsequently the credit risk.

Monetary aggregates considered are the M1, M2, and M3 with the first two being particularly important as they may serve as proxies to the GDP, thus, avoiding potential problems arising from the low-frequency series of the latter.

Any deterioration in market confidence is expected to lead to downward pressure on the exchange rate, upward pressure on interest rates, and declining equity values with the overall result being a deterioration of the Romanian credit portfolio quality. In this respect, the time series employed as financial markets' indicators are the BET index and the BET-C index of the Bucharest Stock Exchange and the over-the-counter market index (RASDAQ). A sharp decline in the stock prices may signal adverse market perceptions of the health of the financial market. The Dow Jones Euro Stoxx 50 equity index is considered as an indicator of the Eurozone economic prospects and markets' expectations. Through the price of oil, a commodity is introduced in the dataset that its price volatility influences almost all economies in the SEE region. A sharp weakening of the Romanian national currency (Ron) against euro would have significant adverse consequences for household and business balance sheets, leading to a substantial increase in Nonperforming loans (IMF [5]). Being a euro candidate country the exchange rate (Ron/Eur) is expected to be of significance. Furthermore, a substantial proportion of the loans granted to households and corporations are denominated in euros. Similarly, the cost of borrowing in such loans is determined by the Euribor reference rate whereas the respective cost in the local currency loans is primarily determined by the Robor rate. Furthermore, any interest rates' hikes increases the probability of loan defaults as borrowers are less able to service their debts.

The determinants of credit risk should not be sought exclusively in macroeconomic factors. A broad set of Romanian aggregated bank-specific indicators is employed to investigate the hypothesis that potential credit risk problems may reside within the core of the banking system. Credit plays a vital role in private sector led growth. Thus, the growth rate of credit is expected to influence the LLP ratio. The loans to deposits ratio serves as a liquidity proxy and gives indications of the ability of the banking system to mobilize deposits to meet credit demand. In addition, it highlights the banks' risk appetite given the lending boom in the precrisis period. The Romanian banking system leverage ratio is considered to validate the moral hazard hypothesis, that is, low capitalisation of banks may amplify the nonperforming loans.

As already mentioned, a substantial part of the Romanian banking system assets is owned by Greek banks. As their "parents" suffer funding shocks due to the Greek sovereign debt turmoil, the local subsidiaries, albeit typically highly liquid and well capitalized [25], face considerable risk of coming under pressure. There is no doubt that the Greek banking system was negatively affected by the Greek fiscal crisis. And banking crises (we refer to Type II banking crises as defined by Reinhart and Rogoff [2]. That is a milder banking crisis also known as financial distress where there are no runs, closure, or large-scale government assistance of an important institution that marks the start of a string of similar outcomes for other financial institutions) have historically been contagious, as a crisis in one country can cause a loss of confidence in neighbouring countries. The novelty of this paper is the introduction of indicators related to the Greek fiscal crisis, the Greek banking system, and the Athens Stock Exchange. The main reasons for selecting the Greek-specific variables presented on Table 3 in the Appendix are as follows.

(a) The rapid expansion of Greek banks in Romania has resulted in imbalances and funding deficits.

(b) The unfolding of the Greek debt crisis is marked in the spread differential between the Greek and German government bonds yields. 
TABLE 1: Results of the univariate regressions.

\begin{tabular}{|c|c|c|c|c|c|c|c|c|c|c|}
\hline & \multicolumn{5}{|c|}{ Regression on current factor $x_{t}$} & \multicolumn{5}{|c|}{ Regression on lagged factor $x_{t-s(s=1 \ldots 12)}$} \\
\hline & Expected sign & Coefficient & $t$-stat & $P$ value & $R^{2}$ & Coefficient & $t$-stat & $P$ value & $R^{2}$ & $\operatorname{lag}(\mathrm{s})$ \\
\hline \multicolumn{11}{|l|}{ Macroeconomic and cyclical indicators } \\
\hline Construction & - & -0.005 & 3.15 & 0.002 & 0.09 & -0.004 & 2.58 & 0.011 & 0.06 & 12 \\
\hline Gross fixed capital formation & - & -0.005 & 3.13 & 0.002 & 0.09 & -0.003 & 2.33 & 0.004 & 0.04 & 12 \\
\hline Total gross external debt/GDP & - & -0.002 & 4.59 & 0.000 & 0.17 & 0.02 & 3.90 & 0.000 & 0.13 & 3 \\
\hline Unemployment & + & -0.001 & 1.98 & 0.049 & 0.04 & -0.001 & 3.75 & 0.000 & 0.13 & 12 \\
\hline Total consumption & - & -0.005 & 2.66 & 0.009 & 0.06 & -0.004 & 2.26 & 0.026 & 0.05 & 1 \\
\hline CPI & - & -0.001 & 5.67 & 0.000 & 0.23 & -0.001 & 4.86 & 0.000 & 0.19 & 3 \\
\hline Trade balance & - & -0.001 & 2.64 & 0.01 & 0.06 & -0.001 & 3.06 & 0.003 & 0.09 & 12 \\
\hline \multicolumn{11}{|l|}{ Monetary indicators } \\
\hline M1 & - & -0.006 & 2.99 & 0.003 & 0.08 & -0.005 & 2.68 & 0.008 & 0.07 & 3 \\
\hline M2 & - & -0.013 & 2.96 & 0.004 & 0.08 & -0.01 & 2.50 & 0.014 & 0.06 & 3 \\
\hline \multicolumn{11}{|l|}{ Interest rates } \\
\hline Euribor 3 month & + & -0.003 & 3.51 & 0.000 & 0.10 & -0.003 & 3.46 & 0.000 & 0.11 & 3 \\
\hline \multicolumn{11}{|l|}{ Romanian banking system indicators } \\
\hline Credit & $+/-$ & -0.03 & 5.16 & 0.000 & 0.2 & -0.02 & 4.10 & 0.000 & 0.14 & 3 \\
\hline \multicolumn{11}{|c|}{ Greek fiscal crisis and banking indicators } \\
\hline Loss Loan Provisions/total loans & + & 0.46 & 2.66 & 0.009 & 0.06 & 0.40 & 2.10 & 0.040 & 0.04 & 3 \\
\hline Spread Greek-German bond & + & 0.01 & 3.24 & 0.000 & 0.09 & 0.01 & 3.00 & 0.000 & 0.08 & 3 \\
\hline Greek 10-year bond & + & 0.01 & 2.45 & 0.021 & 0.05 & 0.01 & 3.50 & 0.000 & 0.10 & 1 \\
\hline ECB Reliance Index I & $+1-$ & 0.04 & 1.71 & 0.090 & 0.03 & 0.07 & 3.87 & 0.000 & 0.13 & 3 \\
\hline
\end{tabular}

Only the significant indicators are presented on the table due to space limitations. The indicator spread Greek-German bond is also significant at lag 1.

(c) The deteriorating asset quality of the Greek banking system together with the strained liquidity is evident in the funding overreliance by the European Central Bank.

(d) The Greek banks offer(ed) investors a good emerging market exposure platform. Consequently, their SEE prospects are reflected in their shares performance in the Athens Stock Exchange.

de Haas and van Lelyveld [26] study of foreign banks in Eastern Europe indicates a significant negative relationship between home country economic growth and host country credit. Thus, the hypothesis under investigation is whether the Greek crisis and banking system dynamics matter for the Romanian Nonperforming loans.

\section{Model Estimation}

The estimation process requires the selection of a set of variables that, according to economic theory and empirical evidence, affect the Romanian credit risk. Broadly, the empirical section consists of three steps.

(a) Unit root tests to ensure time series stationarity.

(b) Univariate regressions to identify the indicators with explanatory power on the LLP ratio of the Romanian banking system.

(c) Estimation, specification, and diagnostic checking of a multivariate model on the basis of variables and theory consistency.
Initially the time series were tested for unit roots by the Augmented Dickey Fuller tests. When a series is found to be integrated of order one $(\mathrm{I}(1))$ or two $(\mathrm{I}(2))$, the first or the second difference of the variable was taken to obtain stationarity. The data transformation(s) can be viewed in Table 4 in the Appendix.

Following an analogous approach to Kalirai and Scheicher [13] and Boss [21], initially we performed OLS univariate regressions to identify the indicators with explanatory power on the LLP ratio of the Romanian banking system. Thus, the monthly changes of the LLP ratio are regressed against each indicator included in Table 3 in the Appendix. The univariate regressions are expected to provide fertile soil for identifying and selecting the factors that have an impact on the dependent variable.

The LLP ratio is regressed against each indicator at time $t$ but also at all lags up to one year. The rationale behind this extensive approach is to capture potential lagged effects of any explanatory variable on the LLP ratio, suggesting that loan provisions appear on banks' financial statements quite after the problem emerges. In addition, this approach enables to analyse the robustness of the models' specification. Table 1 presents the results of the univariate estimations together with the expected signs of the regression coefficients in accordance to theory. A positive (negative) sign suggests that theory or empirical evidence indicates that the respective factor $x_{t}$ (or when lagged, $x_{t-s}$ ) is expected to exhibit a positive (negative) impact on the changes in the LLP ratio.

In accordance to the main body of literature reviewed, an extensive array of the macroeconomic-cyclical indicators 
is found to be significant on the loan portfolio quality of the Romanian banking system. The results indicate that in each category (Table 3, Appendix), with the exception of the financial markets indicators, there is at least one variable that enters significantly the respective regression. Namely, the significant indicators are the construction expenditure, the investment expenditure proxied by the gross fixed capital formation at current levels but also lagged by 12 months, the country's total gross external debt to GDP ratio, the total consumption, the inflation rate, the unemployment rate, and the trade balance. Almost all significant indicators have the expected directional impact on the LLP ratio. The inflation rate produces the highest $t$-statistic and the best fit of all univariate regressions. Thus, the hypothesis that inflationary pressures drive up the nonperforming loans cannot be rejected. None of the financial markets indicators appear to exert a significant role on the dependent variable. Despite the rapid growth of the trading volumes on the Bucharest Stock Exchange in recent years as well as on the over-the-counter market, liquidity remains poor. In contrast to Kalirai and Scheicher [13], volatilities, commodities, and exchange rates do not present any statistically significant impact on the endogenous variable. This can be attributed to the differences between a developed and a less developed country in terms of financial sector structure and deepening. Among the interest rate indicators only the 3-month Euribor rate seem to be a significant parameter at current level but also lagged by a quarter. The negative sign does not support the expectation that credit risk increases in line with interest rates owing to higher borrowing costs. Except for the credit growth rate, all other Romanian bank-specific indicators are insignificant. The steep credit expansion that occurred during the period prior to the burst of the financial turmoil poses the question whether the quality of loans granted during this period was accurately evaluated by the banking system (Louzis et al. [27]). Given the ambiguity (univariate results suggest that an increase in the credit growth rate reduces the Romanian credit risk. i.e., against the procyclical credit policy hypothesis which implies that banks adopt a liberal credit policy during the boom of the cycle and a tighter policy in the contraction phase) apparent in the theory regarding the expected sign of credit, we opt to drop the variable from the final model.

In terms of monetary indicators, both aggregates M1 and M2 help explaining the variability in the LLP ratio with the expected direction. Interestingly, four indicators that proxy the Greek crises' dynamics appear significant while they affect the Romanian LLP at the expected direction. This result comes hand in hand with our expectations in view of the significant Greek presence in the Romanian banking system. It provides grounds to believe that some spillover effects of the Greek debt crisis and banking system distress may have started to manifest themselves.

Building upon the significant factors identified in the bivariate regressions, we estimate a multivariate credit risk model following a general-to-specific methodology. The criteria to arrive at a parsimonious final model formulation are as follows. (a) The indicators in the final specification of the multivariate model should bear the correct sign.

(b) Ideally, at least one significant indicator from each category should be included in the model.

(c) The model should be logically plausible and simple. Such models are easier interpreted and communicated.

(d) All variables included in the multifactor model should be significant both separately and jointly, at least at the $10 \%$ level of significance.

(e) The standard battery of residuals' tests should indicate no pathological issues.

Following the described methodology while satisfying the criteria set previously, the time series model estimated by OLS is presented in Table 2. The diagnostic checks indicate no signs of first- and second-order serial correlation as can be seen by the DW statistic and the Breusch-Godfrey test (Table 5, Appendix), respectively. As there are heteroscedasticity issues in the residuals, the results (Table 2) have been adjusted on the basis of the Newey-West estimators (the Newey-West allows for consistent covariance estimates. It does not change the point estimates of the parameters, only the estimated standard errors). Furthermore, the intercorrelations among the explanatory variables are at reasonable levels (the highest correlation coefficient is 0.037) suggesting no serious multicollinearity issues.

The model's specification indicates that, taken simultaneously, the CPI, the unemployment rate, the construction and the gross fixed capital formation lagged by one year, the ratio of gross external debt to GDP lagged by a quarter, M2 together with the Greek banks' credit risk, and the spread differential between the Greek and the German sovereign debt lagged by one month explain approximately $66 \%$ of the variability of credit risk in the Romanian banking system. The relatively good fit of the regression suggests that the loss loan provisions in the Romanian banking system can be explained reasonably well by macro fundamentals and Greek crises' indicators.

The explanatory power of the Romanian macroeconomic variables such as inflation, unemployment rate, and monetary indicators is in broad agreement with related studies [5, $21,22,27]$. Yet, the idiosyncratic features of the developing economy and also those of a banking system dominated by foreign institutions are also present in the findings. For instance, we find that investment and construction fuelled by the lending boom in the precrisis period and the country's indebtness are among the important factors that influence Romanian credit risk while Kalirai and Scheicher [13] find that financial markets' variables such as the Ifo business climate index, the ATX, the DAX, and the Euro, Stoxx indices are equally significant for a developed economy.

The study is also motivated by the hypothesis that Greekspecific variables influence the Romanian banking system loan quality or alternatively the Greek crises' matter for the neighbourhood (Anastasakis et al. [28]). Based on the findings, this hypothesis cannot be rejected as the Romanian credit risk is responsive and more specific adversely affected 
TABLE 2: Regression output of the multivariate model.

Dependent Variable: loss loan provisions/total loans (R)

Method: Least Squares

\begin{tabular}{|c|c|c|c|c|}
\hline Variable & Coefficient & Std. error & $t$-statistic & Prob. \\
\hline C & 0.000523 & 0.000399 & 1.311663 & 0.1932 \\
\hline CPI & -0.000150 & $3.00 \mathrm{E}-05$ & -4.997403 & 0.0000 \\
\hline Unemployment & 0.000263 & 7.70E-05 & 3.422545 & 0.0010 \\
\hline Construction & -0.003324 & 0.001184 & -2.806879 & 0.0062 \\
\hline Gross fixed capital formation $(-12)^{*}$ & -0.003555 & 0.001441 & -2.466644 & 0.0157 \\
\hline Total gross external debt/GDP $(-3)$ & 0.012220 & 0.002648 & 4.614924 & 0.0000 \\
\hline M2 & -0.008042 & 0.002274 & -3.536230 & 0.0007 \\
\hline Loss loan provisions/total loans (GR) & 0.452571 & 0.194031 & 2.332466 & 0.0221 \\
\hline Spread Greek-German bond $(-1)$ & 0.001251 & 0.000440 & 2.843167 & 0.0056 \\
\hline$R$-squared & 0.657178 & Mean dependent var & & 0.000852 \\
\hline Adjusted $R$-squared & 0.624529 & S.D. dependent var & & 0.001507 \\
\hline S.E. of regression & 0.000923 & Akaike info criterion & & -11.04576 \\
\hline Sum squared resid & $7.16 \mathrm{E}-05$ & Schwarz criterion & & -10.80067 \\
\hline Log likelihood & 522.6277 & F-statistic & & 20.12818 \\
\hline Durbin-Watson stat & 2.261533 & Prob (F-statistic) & & 0.000000 \\
\hline
\end{tabular}

* Numbers in parentheses indicate the lag of the respective variable used in model estimation. All indicators (individually and jointly) included in the model are significant at the $1 \%$ confidence level.

towards risks arising from the neighbourhood. In other words, there is evidence that some spillover effects from the Greek crises have already started to manifest themselves indicating potential contagion risk.

It should be noted that caution is required when interpreting the empirical results. Any attempt should be done under the assumptions made and the time period considered. Future research would attempt to combine the proposed model with the VAR approach while accounting for the default risks at borrower level (households and corporations).

Regarding the model specification, it is worth noting that a number of studies indicate that loan loss provisions and Nonperforming loans may be noisy proxies of credit risk in the banking sector whereas other studies debate the linear functional form of credit risk. As more data become available, the proposed recommendations indicate our future work direction.

\section{Conclusions}

Internationally, the number of empirical studies trying to link macroeconomic factors and the asset quality of the banking sector has been growing rapidly in recent years. Addressing the high level of nonperforming loans remains a major challenge as important postcrisis effects are still unfolding.

In this study we applied time series modelling techniques to investigate the deterministic factors of Nonperforming loans in the Romanian financial system; a system dominated by foreign-owned commercial banks. Credit risk is modelled in dependence of a data-intensive set of indicators ranging from macroeconomic, monetary, financial markets and interest rates to bank-specific variables. The novelty of the study lies in the introduction of proxies for the Greek debt crisis and the Greek banks' financial distress. Apart from the standard hypotheses investigated in the empirical literature, the study is motivated by the hypothesis that the Greek crises matter for the neighbourhood. Empirical findings suggest that macroeconomic variables, specifically the construction and investment expenditure, the inflation and the unemployment rate, and the country's external debt to GDP and M2 together with Greek-specific variables influence the credit risk of the Romanian banking system. On the other hand, the Romanian bank-specific variables, the financial markets, and interest rates indicators were not found to possess explanatory power when added to the baseline model. Based on the findings, the hypothesis that Romanian credit risk is responsive to the country's macro fundaments is confirmed. Furthermore, there is evidence that supports the hypothesis of linking Greek-specific indicators to the quality of the Romanian loan portfolio. The Romanian nonperforming loans seem to be adversely affected by risks arising from the Greek twin crises.

Our findings have several implications in terms of policy and regulation. Specifically, the macroeconomic significant variables identified may serve as leading indicators of credit risk deterioration. As most SEE economies rely heavily on 
TABle 3: The complete dataset.

\begin{tabular}{|c|c|c|}
\hline Indicators & Definition interpretation & Source \\
\hline \multicolumn{3}{|l|}{ Credit risk for the Romanian banking system } \\
\hline Loss loan provisions/total loans (R) & $\begin{array}{l}\text { Doubtful and loss loans provisions to total loans } \\
\text { granted by credit institutions, excluding } \\
\text { off-balance-sheet items }\end{array}$ & $\begin{array}{l}\text { National Bank of Romania } \\
\text { and authors' calculations }\end{array}$ \\
\hline Credit risk & $\begin{array}{l}\text { Gross exposure related to nonbank loans and } \\
\text { interest under "doubtful" and "loss" to total loans } \\
\text { and interest classified related to nonbank loans, } \\
\text { excluding off-balance-sheet items }\end{array}$ & National Bank of Romania \\
\hline Defaulters/Debtors & $\begin{array}{l}\text { Number of total loan debtors to total loan } \\
\text { defaulters (legal and natural entities) }\end{array}$ & National Bank of Romania \\
\hline \multicolumn{3}{|l|}{ Macroeconomic and cyclical indicators } \\
\hline $\mathrm{CPI}$ & Consumer price index annual rate $(\%)$ & European Central Bank \\
\hline GDP & Real gross domestic product & NISR \& Authors' calculations \\
\hline Current account & Current account & National Bank of Romania \\
\hline Current account/GDP & Current account as \% of GDP & Authors' calculations \\
\hline Construction & $\begin{array}{l}\text { Construction sector expenditure contribution in } \\
\text { GDP at constant terms }\end{array}$ & NISR \\
\hline Gross fixed capital formation (investment) & $\begin{array}{l}\text { Investment expenditure contribution in GDP at } \\
\text { constant terms }\end{array}$ & NISR \\
\hline Total consumption & $\begin{array}{l}\text { Total consumption contribution in GDP at } \\
\text { constant terms }\end{array}$ & NISR \\
\hline Household consumption & $\begin{array}{l}\text { Household consumption contribution in GDP at } \\
\text { constant terms }\end{array}$ & NISR \\
\hline FDI monthly stock & Foreign direct investment, net, monthly & National Bank of Romania \\
\hline FDI annual flow & Foreign direct investment, net, accumulated & National Bank of Romania \\
\hline Trade balance & Imports minus exports (constant terms) & National Bank of Romania \\
\hline Unemployment & Registered unemployment rate (\%) & $\begin{array}{l}\text { National Bank of Romania } \\
\text { and European Central Bank }\end{array}$ \\
\hline Total gross external debt & $\begin{array}{l}\text { Total gross external debt (general government, } \\
\text { monetary authority, banks, and other sectors) }\end{array}$ & National Bank of Romania \\
\hline Total gross external government debt & $\begin{array}{l}\text { Total gross external debt general government } \\
\text { (short and long term) }\end{array}$ & National Bank of Romania \\
\hline Total gross external debt banks & $\begin{array}{l}\text { Total gross external debt banks (short and long } \\
\text { term) }\end{array}$ & National Bank of Romania \\
\hline Total gross external debt/GDP & $\begin{array}{l}\text { Total gross external debt as } \% \text { of gross domestic } \\
\text { product }\end{array}$ & Authors' calculations \\
\hline Total gross external debt banks/GDP & $\begin{array}{l}\text { Total gross external debt banks as \% of gross } \\
\text { domestic product }\end{array}$ & Authors calculations \\
\hline
\end{tabular}

Monetary indicators

M1

M2

M3
Narrow money. Comprises currency in circulation plus overnight deposits. Also proxies gross domestic product

Intermediate money. Comprises M1 plus highly liquid deposits.

Broad money. Comprises M2 plus marketable instruments issued by monetary and financial institutions

Historical close, average of observations (\% p.a.)

Historical close, average of observations (\% p.a.)

Historical close, average 3-month interest rate on operations to place funds (\% p.a.)
National Bank of Romania

National Bank of Romania

National Bank of Romania

Reuters

Reuters

National Bank of Romania 
TABle 3: Continued.

\begin{tabular}{|c|c|c|}
\hline Indicators & Definition interpretation & Source \\
\hline Robor 12 months & $\begin{array}{l}\text { Historical close, average } 12 \text {-month interest rate } \\
\text { on operations to place funds ( } \% \text { p.a.) }\end{array}$ & National Bank of Romania \\
\hline Spread differential Euribor-Robor & Euribor $3 \mathrm{M}$ minus Robor 3M & Authors' calculations \\
\hline Romanian long term-bond & $\begin{array}{l}\text { Average interest rate of long-term Romanian } \\
\text { government bond ( } \% \text { p.a.) }\end{array}$ & National Bank of Romania \\
\hline German 10-year bond & $\begin{array}{l}\text { Secondary market yield of 10-year German } \\
\text { government bond }\end{array}$ & European Central Bank \\
\hline Spread Romanian-German bond & $\begin{array}{l}\text { Spread differential between Romanian and } \\
\text { German long-term government bond yield }\end{array}$ & Authors' calculations \\
\hline \multicolumn{3}{|l|}{ Financial markets indicators } \\
\hline BET & $\begin{array}{l}\text { The Bucharest Exchange Trading index. } \\
\text { Comprises the ten most liquid companies listed } \\
\text { on the BSE regulated market }\end{array}$ & National Bank of Romania \\
\hline BET-C & $\begin{array}{l}\text { The Composite Index of Bucharest Stock } \\
\text { Exchange. Represents the overall performance of } \\
\text { all companies listed on the BSE regulated market }\end{array}$ & National Bank of Romania \\
\hline RASDAQ & The index captures the over-the-counter market & National Bank of Romania \\
\hline Dow Jones Euro Stoxx 50 & $\begin{array}{l}\text { Equity index. Indicator of economic prospects } \\
\text { and market sentiment }\end{array}$ & Datastream \\
\hline Athens Stock Exchange (general) & $\begin{array}{l}\text { General Index Athens Stock Exchange } \\
(31.12 .1980=100)\end{array}$ & Bank of Greece \\
\hline Athens Stock Exchange (banks) & $\begin{array}{l}\text { Banking Index Athens Stock Exchange } \\
(31.12 .2005=5000)\end{array}$ & Bank of Greece \\
\hline Oil & Brent crude oil price fob in Euro per barrel & $\begin{array}{l}\text { European Central Bank and } \\
\text { authors' calculations }\end{array}$ \\
\hline Ron/Eur & $\begin{array}{l}\text { Monthly average spot exchange rate on Forex } \\
\text { market }\end{array}$ & European Central Bank \\
\hline Ron/Usd & $\begin{array}{l}\text { Monthly average spot exchange rate on Forex } \\
\text { market }\end{array}$ & European Central Bank \\
\hline Usd/Eur & $\begin{array}{l}\text { Monthly average spot exchange rate on Forex } \\
\text { market }\end{array}$ & European Central Bank \\
\hline \multicolumn{3}{|l|}{ Romanian banking system indicators } \\
\hline Credit & $\begin{array}{l}\text { Total loans granted by Romanian credit } \\
\text { institutions }\end{array}$ & National Bank of Romania \\
\hline Leverage ratio & Capital/assets. Key prudential indicator & National Bank of Romania \\
\hline Liquidity ratio & $\begin{array}{l}\text { Effective liquidity/required liquidity. Measures } \\
\text { banking system liquidity. Key prudential indicator }\end{array}$ & National Bank of Romania \\
\hline Loans to assets & $\begin{array}{l}\text { Loans granted to clients (gross value)/total assets } \\
\text { (gross value). Key prudential indicator }\end{array}$ & National Bank of Romania \\
\hline Loans-to-deposits ratio & Loans/deposits. Proxy for liquidity & $\begin{array}{l}\text { National Bank of Romania } \\
\text { and authors' calculations }\end{array}$ \\
\hline Interest rate on loans & $\begin{array}{l}\text { Average interest rate of credit institutions charged } \\
\text { on loans to nonfinancial corporations and } \\
\text { households ( } \% \text { p.a.) }\end{array}$ & NBR \\
\hline Interest rate on deposits & $\begin{array}{l}\text { Average interest rate paid by credit institutions on } \\
\text { nonfinancial corporations and households time } \\
\text { deposits (\% p.a.) }\end{array}$ & NBR \\
\hline Spread loan-deposit rate & $\begin{array}{l}\text { Interest rate differential between loans and } \\
\text { deposits of on nonfinancial corporations and } \\
\text { households time deposits (\% p.a.) }\end{array}$ & Authors' calculations \\
\hline
\end{tabular}

Greek fiscal crisis and banking system indicators

Loss loan provisions/total loans (GR)

Credit
Loss loans provisions to total loans granted by Greek credit institutions

Total loans granted by Greek credit institutions
Bank of Greece and authors' calculations

Bank of Greece 
TABle 3: Continued.

\begin{tabular}{|c|c|c|}
\hline Indicators & Definition interpretation & Source \\
\hline Leverage ratio & Capital/assets. Key prudential indicator & $\begin{array}{l}\text { Bank of Greece and authors' } \\
\text { calculations }\end{array}$ \\
\hline Loans-to-deposits ratio & Loans/deposits. Proxy for liquidity & Bank of Greece \\
\hline Greek 10-year bond & $\begin{array}{l}\text { Secondary market yield of the } 10 \text {-year Greek } \\
\text { government bond }\end{array}$ & European Central Bank \\
\hline Spread Greek-German bond & $\begin{array}{l}\text { Spread differential between Greek and German } \\
\text { long-term government bond yield }\end{array}$ & Authors' calculations \\
\hline ECB Reliance Index I & $\begin{array}{l}\text { Greek banks' financing by European Central Bank } \\
\text { to total assets of the Greek banking system. Proxy } \\
\text { for the Greek banking system distress as a result of } \\
\text { the fiscal crisis }\end{array}$ & $\begin{array}{l}\text { Bank of Greece and authors' } \\
\text { calculations }\end{array}$ \\
\hline ECB Reliance Index II & $\begin{array}{l}\text { Greek banks' financing by European Central Bank } \\
\text { to total loans of the Greek banking system. Proxy } \\
\text { for the Greek banking system "liquidity gap" }\end{array}$ & $\begin{array}{l}\text { Bank of Greece and authors' } \\
\text { calculations }\end{array}$ \\
\hline
\end{tabular}

TABLE 4: Unit root tests of significant variables.

\begin{tabular}{|c|c|c|c|c|c|}
\hline & $\begin{array}{l}\text { ADF test statistic } \\
\quad(\text { constant })\end{array}$ & $P$ value & $\begin{array}{l}\text { ADF test statistic } \\
\text { (constant and trend) }\end{array}$ & $P$ value & Transformation \\
\hline \multicolumn{6}{|l|}{ Credit risk } \\
\hline Loss loan provisions/total loans (R) & $-2.898^{*}$ & 0.049 & -3.775 & 0.021 & First differences \\
\hline \multicolumn{6}{|l|}{ Macroeconomic and cyclical indicators } \\
\hline Construction & -7.471 & 0.000 & -7.952 & 0.000 & First differences logs \\
\hline Gross fixed capital formation & -7.573 & 0.000 & -8.079 & 0.000 & First differences logs \\
\hline Total gross external debt/GDP & $-3.026^{*}$ & 0.035 & $-3.228^{* *}$ & 0.084 & First differences \\
\hline Unemployment & -6.024 & 0.000 & -4.600 & 0.001 & None \\
\hline Total consumption & -7.855 & 0.000 & -8.247 & 0.000 & First differences logs \\
\hline CPI & -5.767 & 0.000 & $-3.320^{* *}$ & 0.068 & None \\
\hline Trade balance & -11.400 & 0.000 & -11.398 & 0.000 & First differences \\
\hline \multicolumn{6}{|l|}{ Monetary indicators } \\
\hline M1 & -2.648 & 0.008 & -12.919 & 0.000 & First differences logs \\
\hline M2 & -12.393 & 0.000 & -12.590 & 0.000 & First differences logs \\
\hline \multicolumn{6}{|l|}{ Interest rates indicators } \\
\hline Euribor 3 month & -4.190 & 0.001 & -4.180 & 0.006 & First differences \\
\hline \multicolumn{6}{|l|}{ Romanian banking system indicators } \\
\hline Credit & -4.246 & 0.000 & -4.480 & 0.002 & First differences logs \\
\hline \multicolumn{6}{|l|}{$\begin{array}{l}\text { Greek fiscal crisis and banking } \\
\text { indicators }\end{array}$} \\
\hline Loss loan provisions/total loans & -5.093 & 0.000 & -5.237 & 0.000 & Second differences \\
\hline Spread Greek-German 10-year bond & -3.742 & 0.004 & -4.461 & 0.002 & First differences \\
\hline Greek 10-year bond & $-2.673^{* *}$ & 0.082 & $-3.387^{*}$ & 0.058 & First differences \\
\hline ECB Reliance Index I & -8.885 & 0.000 & -9.397 & 0.000 & First differences \\
\hline
\end{tabular}


TABLE 5: Serial correration test for the multivariate model.

\begin{tabular}{|c|c|c|c|c|}
\hline \multicolumn{5}{|c|}{ Breusch-Godfrey LM test: } \\
\hline$F$-statistic & 0.882585 & Probability & & 0.417605 \\
\hline Obs $* R$-squared & 1.959774 & Probability & & 0.375354 \\
\hline \multicolumn{5}{|c|}{ Dependent variable: RESID } \\
\hline \multicolumn{5}{|l|}{ Method: least squares } \\
\hline Variable & Coefficient & Std. Error & $t$-statistic & Prob. \\
\hline$C$ & $-2.58 \mathrm{E}-05$ & 0.000457 & -0.056394 & 0.9552 \\
\hline CPI & $1.74 \mathrm{E}-06$ & $3.29 \mathrm{E}-05$ & 0.052775 & 0.9580 \\
\hline UN & $5.81 \mathrm{E}-06$ & $8.23 \mathrm{E}-05$ & 0.070535 & 0.9439 \\
\hline DLCSTR & -0.000492 & 0.001445 & -0.340164 & 0.7346 \\
\hline DLGFC $(-12)$ & -0.000377 & 0.001469 & -0.256693 & 0.7981 \\
\hline DTGG $(-3)$ & 0.000669 & 0.003086 & 0.216803 & 0.8289 \\
\hline DLM2 & -0.000382 & 0.003037 & -0.125784 & 0.9002 \\
\hline DDLLPG & 0.005805 & 0.120944 & 0.047998 & 0.9618 \\
\hline $\operatorname{DSPGD}(-1)$ & $-7.79 \mathrm{E}-05$ & 0.000446 & -0.174853 & 0.8616 \\
\hline $\operatorname{RESID}(-1)$ & -0.157716 & 0.118716 & -1.328516 & 0.1877 \\
\hline $\operatorname{RESID}(-2)$ & -0.033249 & 0.120267 & -0.276463 & 0.7829 \\
\hline$R$-squared & 0.021073 & Mean dependent var & & $9.21 \mathrm{E}-20$ \\
\hline Adjusted $R$-squared & -0.098309 & S.D. dependent var & & 0.000882 \\
\hline S.E. of regression & 0.000924 & Akaike info criterion & & -11.02404 \\
\hline Sum squared resid & $7.01 \mathrm{E}-05$ & Schwarz criterion & & -10.72449 \\
\hline Log likelihood & 523.6181 & $F$-statistic & & 0.176517 \\
\hline Durbin-Watson stat & 1.979081 & Prob (F-statistic) & & 0.997482 \\
\hline
\end{tabular}

the financial sector in terms of growth prospects, regulators should ensure financial stability by remaining vigilant on the neighbouring countries' macroeconomic prospects and the potential contagion risk arising from the Greek banks' subsidiaries in Romania.

\section{Appendix}

For more details see Tables 3, 4, and 5.

\section{References}

[1] R. Merton, "On the pricing of corporate debt: the risk structure of interest rates," Journal of Finance, vol. 29, pp. 449470, 1974.

[2] C. Reinhart and K. Rogoff, This Time is Different. Eight centuries of Financial Folly, Princeton University Press, Princeton, NJ, USA, 2009.

[3] S. Barisitz, "The transformation of the Romanian financial and banking sector," OeNB Financial Stability Report 7, 2005.

[4] J. Bonin, I. Hasan, and P. Wachtel, "Banking in transition countries," BOFIT Discussion Papers, no. 12, 2008.

[5] IMF, "Romania: financial sector stability assessment," Country Report 10/47, 2010.

[6] M. Gavin and R. Hausmann, "The roots of banking crises: the macroeconomic context," Inter-American Bank Working Paper, no. 318, pp. 1-20, 1996.

[7] D. W. Diamond and R. G. Rajan, "Liquidity shortages and banking crises," Journal of Finance, vol. 60, no. 2, pp. 615-647, 2005.
[8] A. Demirgüç-Kunt and E. Detragiache, "The determinants of banking crises in developing and developed countries," IMF Staff Papers, vol. 45, no. 1, pp. 81-109, 1998.

[9] D. Hardy and C. Pazarbasioglu, "Leading indicators of banking crisis: was Asia different?" IMF Working Paper, no. 91, pp. $1-32,1998$.

[10] T. Wilson, "Portfolio credit risk (I)," Risk, vol. 10, no. 9, 1997.

[11] T. Wilson, "Portfolio credit risk (II)," Risk, vol. 10, no. 10, 1997.

[12] J. Pesola, "The role of macroeconomic shocks in banking crises," Bank of Finland Discussion Paper, no. 6, 2001.

[13] H. Kalirai and M. Scheicher, "Macroeconomic stress testing: preliminary evidence for Austria," OeNB, Financial Stability Report 3, pp. 58-74, 2002.

[14] J. Delgado and J. Saurina, "Credit risk and loan loss provisions. An analysis with macroeconomic variables," Banco de Espana Working Paper, no. 12, 2004.

[15] C. Sims, "Macroeconomics and reality," Econometrica, no. 48, 1980.

[16] W. Blaschke, M. Jones, G. Majnoni, and S. M. Peria, "Stress testing of financial systems: an overview of issues, methodologies, and FSAP experiences," IMF Working Paper, vol. 188, pp. 2-56, 2001.

[17] G. Hoggarth, A. Logan, and L. Zicchino, "Macro stress tests of UK banks," BIS Papers, no. 22, pp. 392-408, 2005.

[18] M. Gambera, "Simple forecasts of bank loan in the business cycle," Emerging Issues Series, vol. 3, pp. 1-27, 2000.

[19] I. Baboucek and M. Jancar, "Effects of macroeconomic shock to the quality of the aggregate loan portfolio," Czech National Bank, Working Paper, vol. 1, pp. 1-62, 2005.

[20] A. Foglia, "Stress testing credit risk: a survey of authorities' approaches," Bank of Italy Working Paper, no. 37, 2008. 
[21] M. Boss, "A macroeconomic credit risk model for stress testing the Austrian credit portfolio," OeNB, Financial Stability Report 4, 2002.

[22] I. Trenca and A. Benyovszki, "Credit risk, a macroeconomic model application for Romania," Finance and Challenges of the Future, vol. 7, pp. 118-126, 2008.

[23] K. Virolainen, "Macro stress testing with a macroeconomic credit risk model for finland," Bank of Finland Discussion Papers, no. 18, 2004.

[24] F. Kalfaoglou, "Stress testing of the Greek banking system," Bank of Greece Economic Bulletin, vol. 27, pp. 43-62, 2006.

[25] NBR, "Financial stability report 2010," Tech. Rep., 2011.

[26] R. de Haas and I. van Lelyveld, "Foreign banks and credit stability in Central and Eastern Europe. A panel data analysis," Journal of Banking and Finance, vol. 30, no. 7, pp. 1927-1952, 2006.

[27] D. Louzis, A. Vouldis, and V. Metaxas, "Macroeconomic and bank-specific determinants of non-performing loans in Greece: a comparative study of mortgage, business and consumer loan portfolios," Bank of Greece Working Paper, no. 110, pp. 1-41, 2010.

[28] O. Anastasakis, J. Bastian, and M. Watson, From Crisis to Recovery. Sustainable Growth in South East Europe, South East European Studies at Oxford, University of Oxford, Oxford, UK, 2011. 


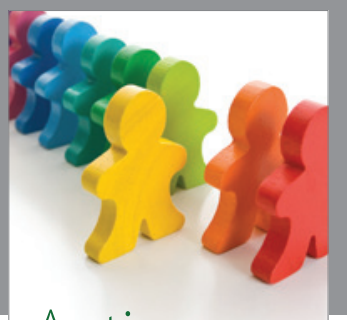

Autism

Research and Treatment
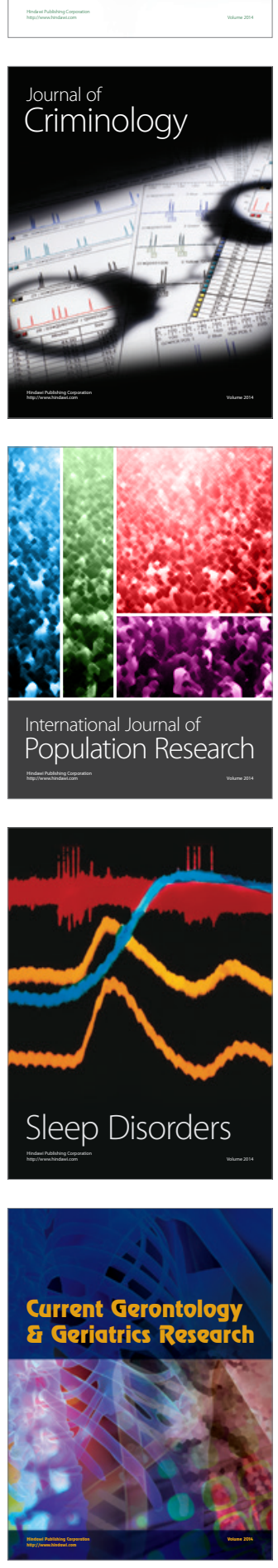
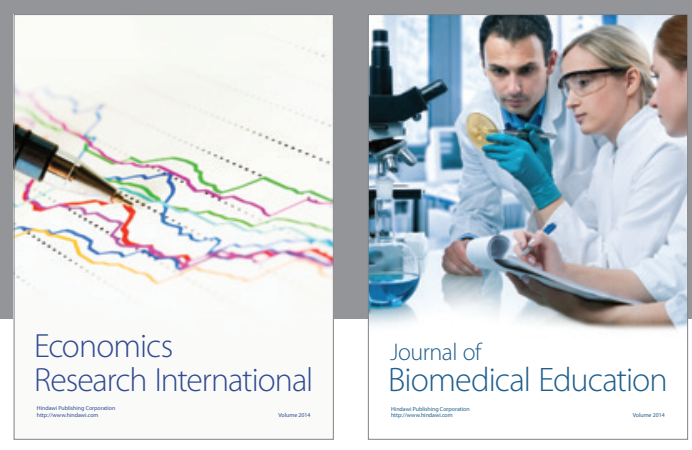

Journal of

Biomedical Education

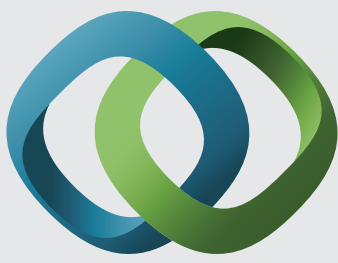

\section{Hindawi}

Submit your manuscripts at

http://www.hindawi.com
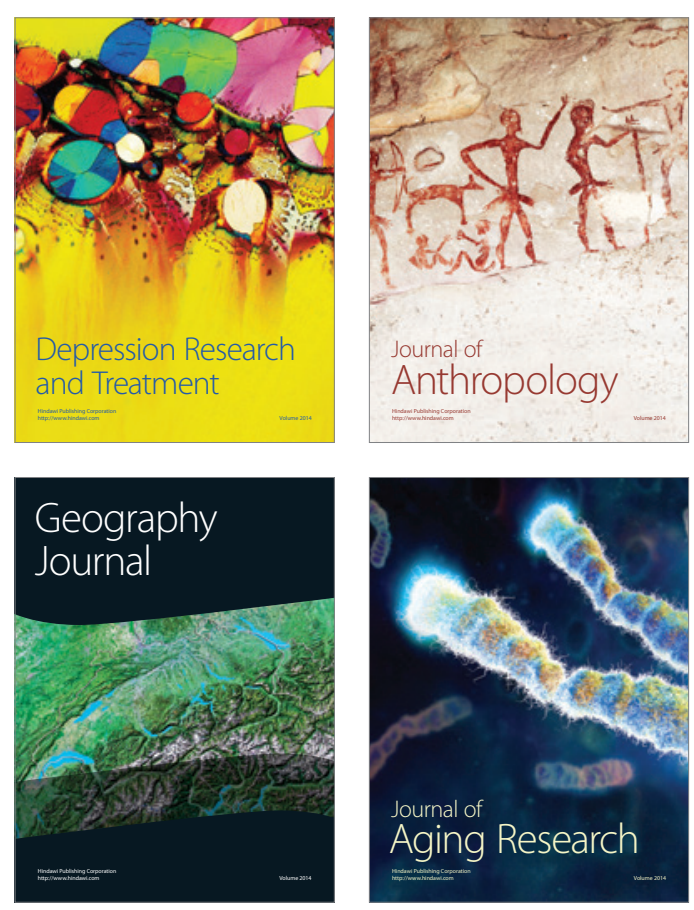

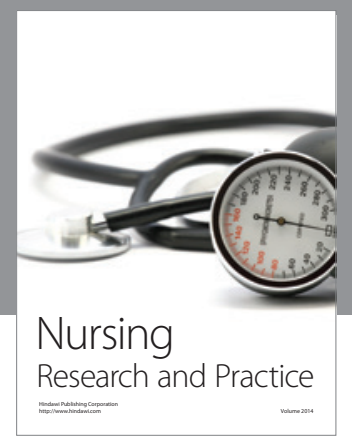

Nursing

Research and Practice

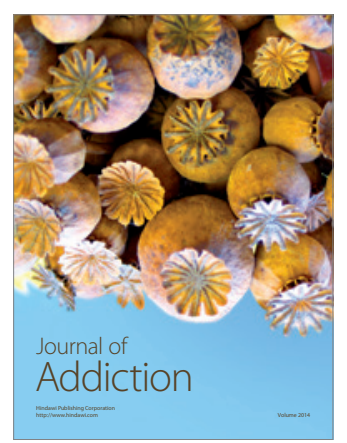

Child Development

Research

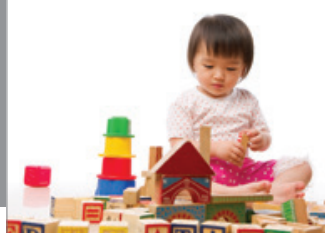

迥
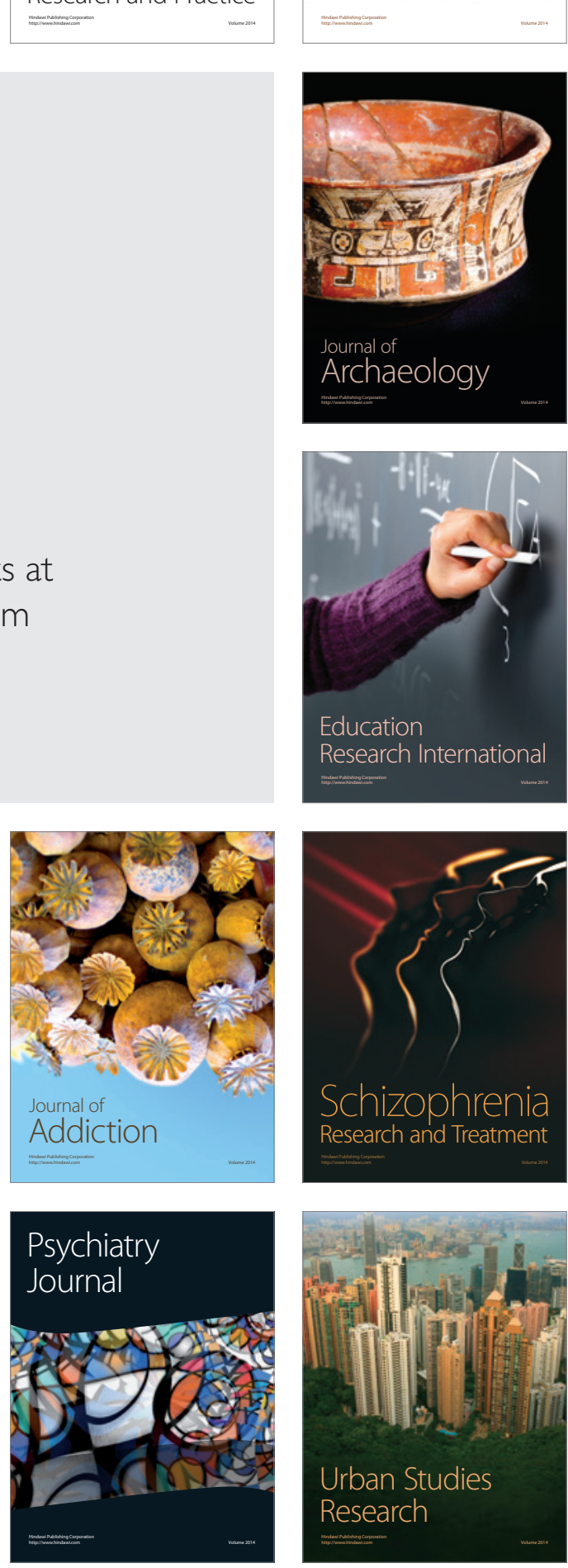